\title{
Traceological analysis of a singular artefact: The rock crystal point from $O$ Achadizo (Boiro, A Coruña, Galicia)
}

\author{
Juan Luis Fernández-Marchena ${ }^{1}$, Andreu Ollé ${ }^{2,3}$, Alba Antía \\ Rodríguez-Nóvoa ${ }^{4}$, Estevo Amado-Rodríguez ${ }^{4}$, Mikel Díaz-Rodríguez ${ }^{4}$, \\ Raquel Pérez-Tenorio ${ }^{3,2}$, María Jesús de la Torre-Llorca ${ }^{5}$ \\ 1. Seminari d'Estudis i Recerques Prehistòriques (SERP). Secció Prehistòria i Arqueologia, Facultat de \\ Geografia i Història, Universitat de Barcelona, c/Montalegre 6-8, 08001 Barcelona, Spain. \\ Email: juanl.ferna@gmail.com \\ 2. Institut Català de Paleoecologia Humana i Evolució Social (IPHES), Zona educacional 4 (Edifici W3), \\ Campus Sescelades URV, 43007 Tarragona, Spain. Email: aolle@iphes.cat \\ 3. Àrea de Prehistòria, Universitat Rovira i Virgili, Facultat de Lletres, Avinguda Catalunya 35, 43002 \\ Tarragona, Spain. Email: raquel.p.t.91@gmail.com \\ 4. Grupo de Estudo para a Prehistoria do NW Ibérico (GEPN), Departamento de Historia I. Praza da \\ Universidade, 15782 Santiago de Compostela, Spain. \\ Email: Rodríguez-Nóvoa: albaantia.rodriguez@gmail.com; Amado-Rodríguez: estevoamado@gmail.com; \\ Díaz-Rodríguez: mikel.diaz.rodriguez@gmail.com \\ 5. GI-1548: HAMED Historia Medieval: Sociedad y Territorio, Departamento de Historia Medieval e Moderna. \\ Praza da Universidade, nº 115782 Santiago de Compostela, Spain. Email: majedelatorre@gmail.com
}

\begin{abstract}
:
The stone knapping industry is largely unknown from Galician Iron Age hillforts. Research into the material culture of these settlements is increasingly diverse, meaning this research is no longer reduced to techno-typological studies of pottery and metals, but also includes a wide range of approaches, including anthracological and carpological analyses, macrolithic tools, and so on. However, there have still been no studies on knapped stone tools. This gap in the research, which may be dependent on various factors, limits the overall perception of the economy of these communities.

In this paper we present the data obtained from a use-wear study of a rock crystal tool from the $\mathrm{O}$ Achadizo hill fort (Boiro, A Coruña, Galicia). This tool was located in shell midden A, dated as Second Iron Age, and is of particular importance because of its pointed morphology and the configuration evidence on its perimeter. We carried out a macroscopic and microscopic analysis to obtain as much data on this piece as possible. Macroscopically we identified retouching as well as an impact fracture, and at the microscopic level we found several series of striations on the ventral face which are not in keeping with the use of the piece as a projectile tip. We decided to generate several "gigapixel" images of different areas of the tool, in order to record the order and arrangement of these striations, and to understand their origin. We identified differential orientation of the striations in the various sectors of the tool, suggesting a technical origin. The combination of the macro and microscopic analysis of both faces has allowed us to functionally interpret the tool as a sharp element.
\end{abstract}

Keywords: use-wear analyses; rock crystal; Iron Age, Castro-culture; lithic industry

Published by the School of History, Classics and Archaeology, University of Edinburgh ISSN: 2055-0472. URL: http://journals.ed.ac.uk/lithicstudies/

This work is licensed under a Creative Commons Attribution 2.5 UK: Scotland License. 


\section{Resumen:}

La industria lítica tallada de los castros gallegos de la Edad del Hierro es una gran desconocida. Actualmente, la investigación sobre la cultura material de los yacimientos de la Edad del Hierro está siendo cada vez más diversa. Por tanto, ya no se reduce a tipologías y estudios técnicos de cerámicas y metales, incluyendo también una variada gama de aproximaciones, como por ejemplo; estudios antracológicos y carpológicos, estudio de artefactos macrolíticos, etc. Por el contrario, no se han llevado a cabo estudios sobre la industria lítica tallada.

En este artículo presentamos los datos obtenidos desde el estudio traceológico de un útil de cristal de roca del castro de O Achadizo (Boiro, A Coruña, Galicia). Este útil fue recuperado del conchero A, datado en la II Edad del Hierro, siendo de particular importancia por su morfología apuntada y la evidencia de configuración en su perímetro. Para el estudio de esta pieza, llevamos a cabo un análisis macroscópico y microscópico con el objetivo de obtener el mayor índice de datos posible. Macroscópicamente identificamos retoque y una fractura de impacto, y microscópicamente, series de estrías por la cara ventral discordantes con un posible uso como punta de proyectil. Debido al orden que presentaban dichas estrías en diferentes áreas de la pieza, decidimos realizar varias imágenes "gigapixel” con el fin de comprender el origen de esa disposición. De esta forma hemos podido comprobar como la disposición diferencial de las estrías en varias zonas de la pieza sugieren un origen técnico. La combinación del análisis macro y microscópico sobre las dos caras muestra la función del útil como elemento punzante.

Palabras clave: traceología; cristal de roca; Edad del Hierro; cultura Castrexa; industria lítica

\section{Introduction}

The recovery of a rock crystal lithic tool from the O Achadizo hillfort (Boiro, A Coruña, northwestern Iberia) has allowed us, for the first time, to systematically study a knapped lithic tool from the so-called Castro culture. The tool is contextualised in the Second Iron Age (from 4th to 2nd centuries B.C.E.). Due to the scarcity of studies on the knapped stone industry of this culture, we considered it necessary to obtain as much information as possible about this object for which reason we undertook a use-wear analysis.

\subsection{Use-wear analyses}

In functional studies, the main objective of use-wear analyses is to document the deformation of archaeological objects as a consequence of their use. This process should establish whether the object has or has not been used. However, this first phase of the analysis cannot always be performed for various reasons, including the presence of patinas (e.g., LeviSala 1986; 1996; Plisson \& Mauger 1988) or alteration of the surfaces by other postdepositional agents such as trampling (Asryan et al. 2014; Shea \& Klenck 1993), or inadequate treatment of the objects in the process of studying or storing them (Gutiérrez Sáez 1988).

One of the main problems in the microscopic study of use-wear traces is the equifinality with other types of traces. So, those formed by post-depositional processes, such as soil gloss and several types of edge damage (Ollé et al. 2016; Pargeter 2012; Shea \& Klenck 1993) clearly overlap in appearance. This can be explained simply due to the fact that most traces are formed by similar mechanical processes, which are mainly frictional and derive from attritional or abrasive effects (e.g., Brink 1978; Kamminga 1979; Ollé \& Vergès 2008; Pedergnana \& Ollé 2017; Yamada 1993). Because of this, in use-wear analysis the distribution of the traces must be differentiated in order not to confuse the wear created by use with that from, for example, rubbing with the sediment itself, or trampling (Plisson 1985). 
Although the discipline has gone through several methodological stages, involving discussions on the most appropriate technical means for functional analysis (among others, Keeley 1974; 1980; Odell 1975; 1981; Odell \& Odell-Vereecken 1980; Tringham et al. 1974), it is true that there is no general agreement on certain limitations of the discipline. Despite methodological “conciliation” (e.g., Marreiros et al. 2015; Olausson 1993), the inability, for instance, to distinguish the chipping caused by use from that resulting from postdepositional processes, or even small retouch removals, in our view lends more weight to the use of high magnifications. In addition, in the functional analysis of projectiles a mixed method (macro and micro) has often been used (Fischer et al. 1985). In this case, fractures and removal of material by impacts were distinguished from microchipping caused by other actions, such as cutting or scraping. Moreover, in recent years various trampling experiments have been carried out in order to identify different diagnostic impact fractures, i.e., those that cannot be produced by post-depositional processes (Pargeter 2011; 2013; Pargeter \& Bradfield 2012).

Finally, one of the most important variables when performing functional analyses, and one which often goes unnoticed, is the raw material itself. In this case, and due to the scarce literature specifically dealing with rock crystal (Pignat \& Plisson 2000; Plisson 2008), we have based our understanding of this material on our own ongoing experiments and analyses, which have been partially published (Fernández-Marchena \& Ollé 2016; Fernández-Marchena et al. in press; Ollé et al. 2016).

Due to the fact that the transparency and reflectance of rock crystal cause problems for both diacritical readings and macrofracture documentation, several authors have proposed the use of coatings. Although the techniques and products used for coating have been known since the beginning of the discipline (Broadvent \& Knutsson 1975; Semenov 1964), they have been largely ignored. The products and techniques successfully used include sprinkled magnesite, Chinese ink, staining with methyl violet, some kind of unspecified metallization (Semenov 1964), ammonium chloride (Salmiak), Salmiak mixed with white ink, and magnesium (Broadvent \& Knutsson 1975). Other possible coatings are those traditionally required for SEM analysis, such as gold or carbon sputter coatings. Gold coatings are valid for both macro and micro analyses, and in fact offer very good results when used with an OLM (Fernández-Marchena \& Ollé 2016). Of course one of the limiting factors of all these coatings to be used on archaeological materials is their lack of reversibility (Ollé \& Vergès 2008; 2014).

\subsection{The archaeological site of $O$ Achadizo}

The O Achadizo hillfort (Boiro, A Coruña) is a coastal site, located on the Barbanza peninsula (Figure 1). Radiocarbon dating (Rubinos Pérez et al. 1999) and the material culture situate the site between the early Iron Age (9th to 4th centuries B.C.E.) and the medium era (4th to 2nd centuries B.C.E.) (Concheiro Coello 2008). The site is located below the current village of Cabo de Cruz. It was partially destroyed by the construction of various buildings, and excavated in three different phases in order to prevent its complete destruction.

The total area excavated extends for 160 square metres, and corresponds with the perimeter area of a settlement. Despite the limited excavation area, it has been possible to identify at least two different areas bounded by wall structures: a residential zone with a circular house, and a shell-midden or rubbish dump. The tool analysed in this paper was found in the shell-midden (A), dated using 14C from charcoal as $2361 \pm 30$ B.P. (Rubinos Pérez et al. 1999) and is included in the Second Phase of the Galician Iron Age (Pre-Roman). The excavated area of this shell-midden is around 24 square metres and is bounded by a wall (B). It contained about 25,000 fragments of indigenous ceramics. These include the typical 
Rías Baixas pottery, particularly Toralla-type jugs and pots and Cíes-type storage vessels (Figure 2). Finally, some imported material was also found: glass paste beads, amphorae and table ware. These materials, scarce when compared to other sites, point to the arrival of foreign products from the 5th and 4th centuries B.C.E., without there being any material beyond the 1st century B.C.E. (Concheiro Coello \& Vilaseco Vázquez 2011).
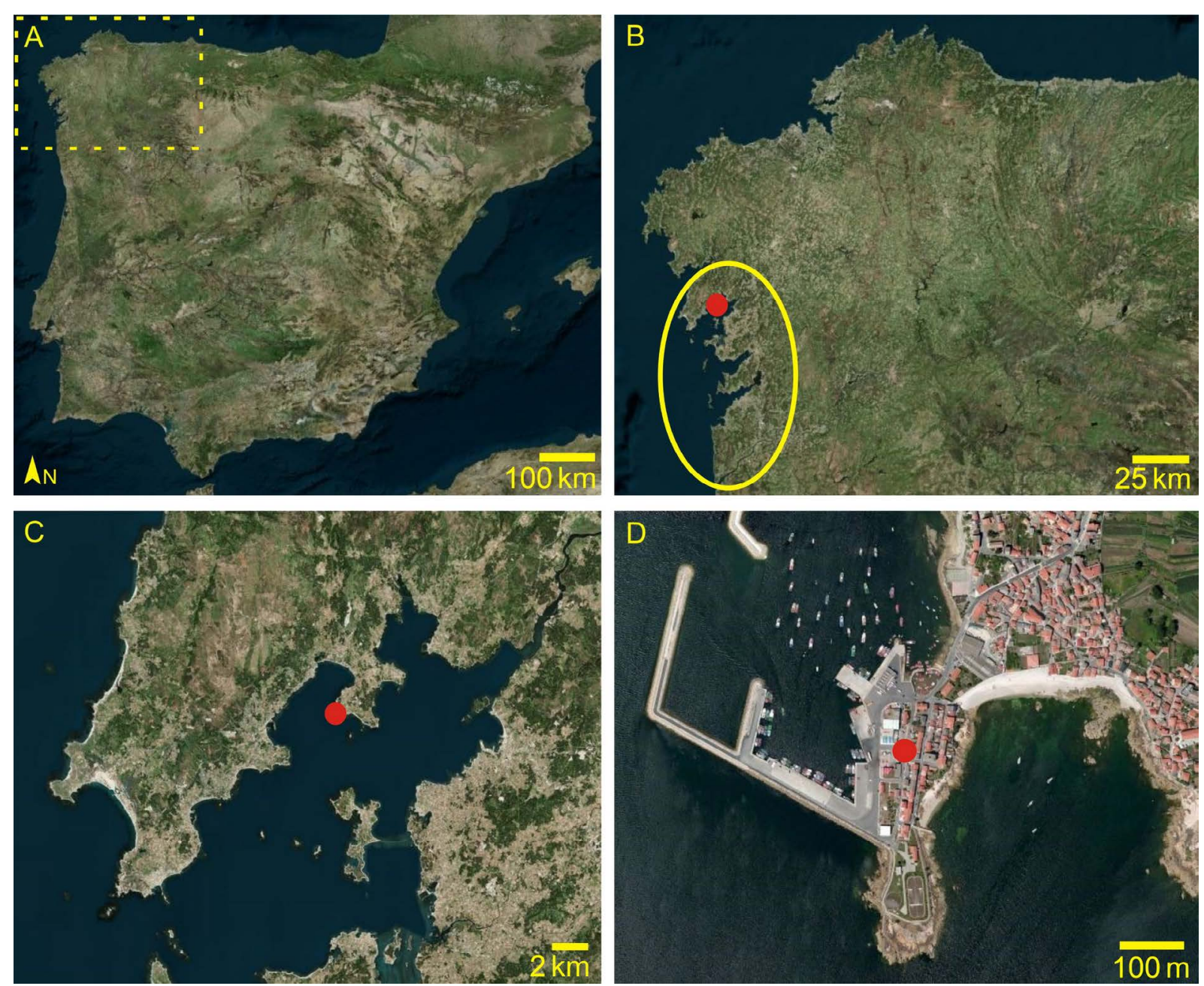

Figure 1. Location of the Achadizo Hillfort. A. Iberian Peninsula; B. the area of Galicia and surrounding region with the Rias Baixas zone within the yellow circumference, the red dot marks the peninsula of Barbanza; C. Barbanza peninsula with a red point indicating the hillfort of $\mathrm{O}$ Achadizo in the Ria de Arousa; D. Harbour of Cabo de Cruz with a red dot indicating the excavation area.

With regard to subsistence media in $\mathrm{O}$ Achadizo, the faunal assemblages are homogeneous throughout the Pre-Roman sequence. Terrestrial faunal remains comprise domesticated and wild species. Domesticated animals were fundamental for the inhabitants of the hillfort and are represented in order of importance by ovicaprini, Bos taurus and Sus sp. In the coastal Castro-culture, ovicaprini is the predominant faunal group, and in the case of this settlement, as in other sites in the area, sheep, goats and pigs were consumed as immature individuals. By contrast, bovids were kept until they had reached optimum size and therefore maximum meat value. This could mean that they were bred not only for meat, but also as working animals or for milk (Fernández Rodríguez 2001). There was some hunting activity (especially cervidae), apparently not due to food needs but for obtaining other resources, such as antlers and hides. We must stress that bones and antlers, from both domestic and wild animals, were used as a raw material (Fernández Rodríguez 2001). The ongoing zooarchaeological studies have so far found no evidence of animal processing in the form of 
cut marks produced by lithic artefacts; only those made by metal knives have been identified (Greenfield 1999) (Figure 3).
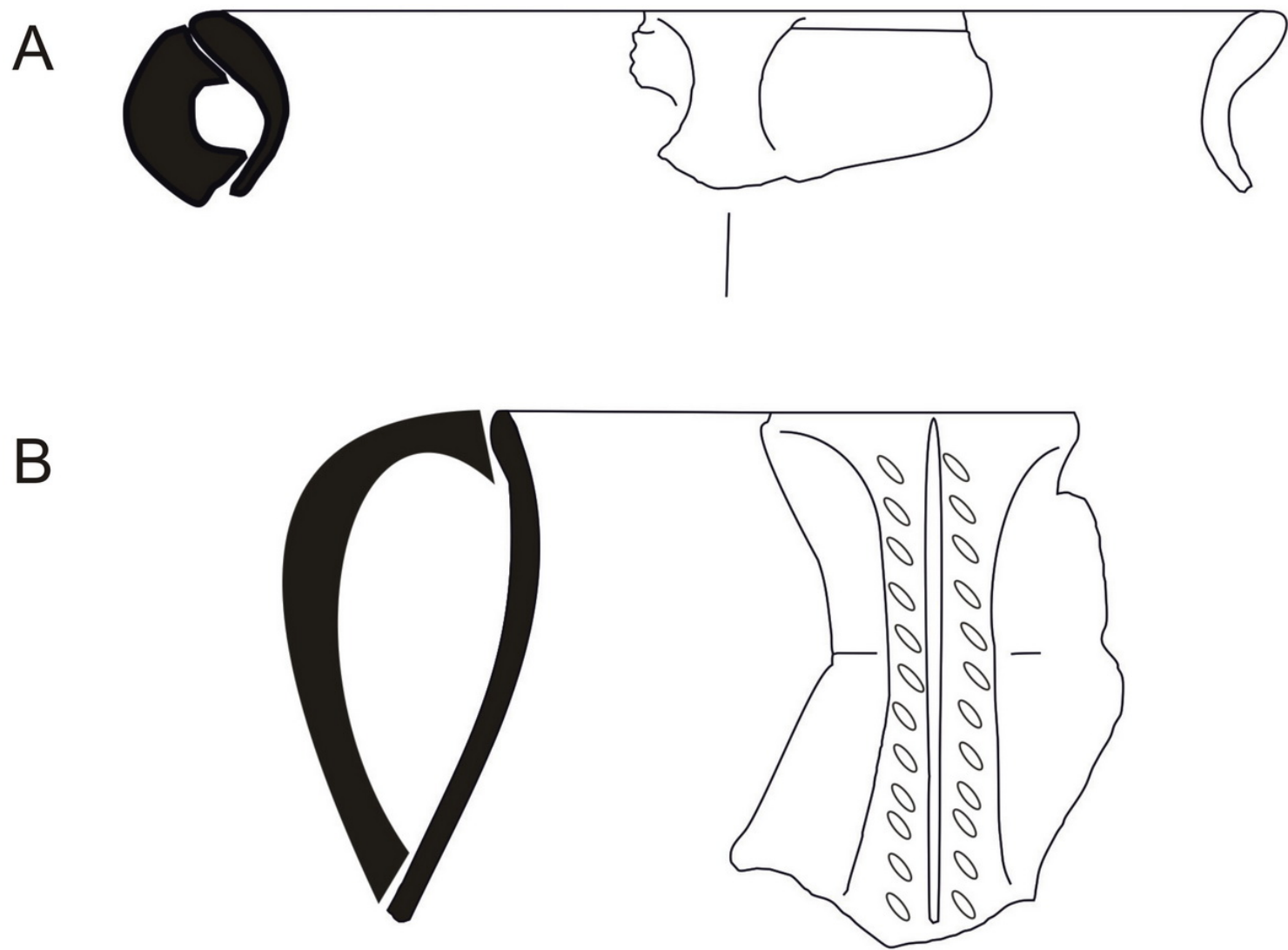

Figure 2. Two examples of from the Second phase of the Galician Iron Age found in the shell-midden (A); A. Toralla-type pot; B. Toralla-type jar.

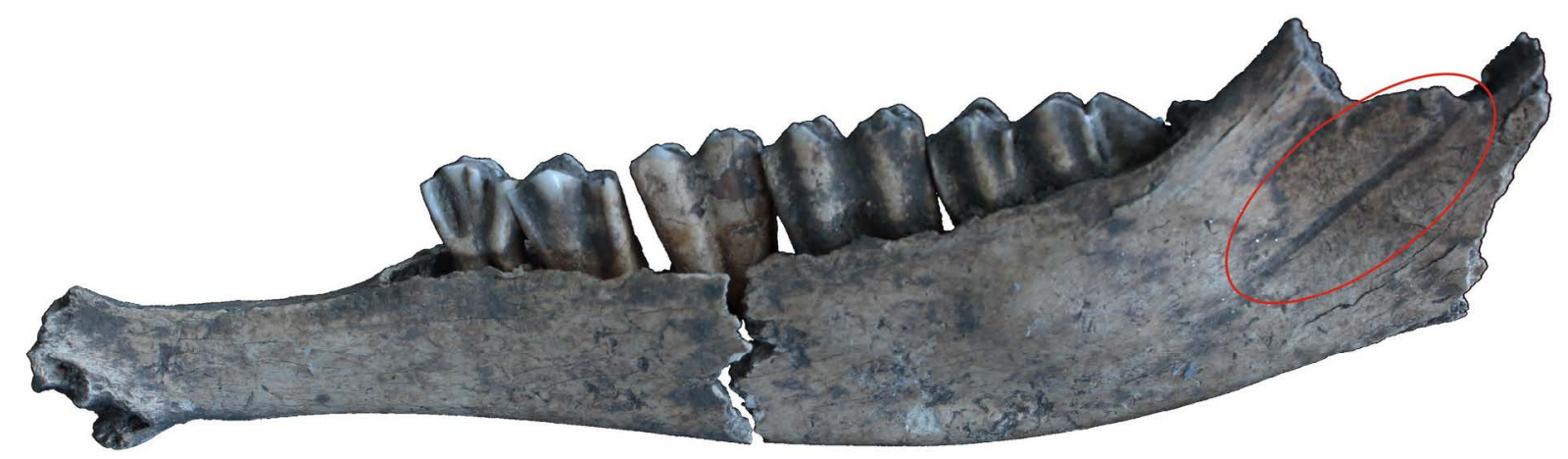

Figure 3. Ovicaprini mandible with a cut mark produced by a metallic tool.

The location of the hillfort on a small promontory in the south of the peninsula of Barbanza (Figure 1C \& D) gives the site a clear coastal character. Exploitation of coastal resources was fundamental, both fishing and shellfishing. More than ten species of fish were caught, of which three were particularly important in pre-Roman times: Sparus aurata, Pagellus bogaraveo and Trisopterus luscus (Ferré et al. 1996). The significance of fishing is also attested to by the appearance of a bronze hook (Concheiro Coello 2008). Five species of shellfish are predominant in all the shell-middens of the hillfort, and were probably collected 
around the site: Patella spp., Mytilus edulis, Littorina littorea, Veneruppis decussate and Ostrea edulis (Rodríguez López et al. 1993).

\subsection{Knapped lithics in the Galician Iron Age?}

The discovery of knapped lithic tools in the Galician hillforts, although not unheard of, is quite exceptional. Despite this exceptionality, no specialised studies have been conducted on them. The absence of specialists in lithic technology in the teams working at these sites, the scarcity of planned excavations, and even the non-collection of lithic artefacts, are some of the main reasons for the underrepresentation of the knapped stone industry in the archaeological literature of this period.

One of the most controversial issues was the appearance of knapped cobbles in the hillforts. Despite the difficulty of reconciling the chronology and cultural affiliation of these tools, the study of these artefacts in SW Galicia allowed two different cultural horizons to be established: Forca and Santa Trega (pre- and post-Roman, respectively) (Cano Pan 1985; 1987; Cano Pan \& Vázquez Varela 1987). Among the tools, all made of quartzite, are knapped cobbles, proto-discs, cores, flakes and weights.

With the exception of a burin from a site in northern Galicia (Ramil Rego et al. 1995), from surface collection, virtually all the Galician Iron Age knapped lithic production was located in the area of the Rías Baixas (Figure 1B). In the Neixón Hillforts (Boiro, A Coruña) quartz and quartzite flakes, and flaked cobbles were recovered, as well as some fragments of knapped schist (Ayán Vila \& Gianotti García 2006; Ayán Vila 2012a; 2012b; 2012c; 2012d; Bonilla Rodríguez \& Fábregas Valcarce 2011; González Pérez \& Ayán Vila 2012). At Pena Redonda (Pontecaldeas, Pontevedra) a flint core, pointing to long distance exchanges, was recorded (González Ruibal 2005), whereas in Montealegre (Moaña, Pontevedra), 12 rock crystal prisms, which could be used as supports for laminar extraction, together with 9 other quartz and rock crystal artefacts (eight flakes and a core) were recovered. A retouched blade fragment interpreted as a sickle element was also found (Cancela Cereijo 2006). Additionally, three flint blades from the Torroso hillfort (Mos, Pontevedra) have also been interpreted as sickles (Peña Santos 1992).

\section{Material and Methods}

For this research, due to the exceptional circumstance of just a single lithic tool from the O Achadizo site, we decided to analyse it in detail. We employed several methods and analytical techniques in order to glean as much information as possible from the tool. Although in this paper we do not present our experimental data or images of experimental tools, essential in any use-wear study, we have based our results on data obtained in previous experimental work we have undertaken on this raw material, some of which is already published (Fernández-Marchena \& Ollé 2016; Fernández-Marchena et al, in press; Ollé et al. 2016).

\subsection{Use-wear analyses, optical media and software}

For the use-wear analysis, we followed the basic methodology guides proposed by the so-called high-power school (Keeley 1980), with some technical adjustments necessary in order to analyse highly reflective materials including rock crystal (Fernández-Marchena \& Ollé 2016; Igreja 2009; Pignat \& Plisson 2000). Due to the large fracture present in the distal area of the tool, we also used the method for analysing the function of lithic projectiles (Fischer et al. 1984) that combines macro- and microscopic analysis. For both analyses we used an optical reflected light microscope, the Zeiss Axioscope A.1, with a Nomarski prism 
and a DIC system (Differential Interference Contrast), which produces a 3D-like image. The microscope is equipped with a $5 \mathrm{Mpx}$ Invenio 5S vII camera, connected to DeltaPix Insight software. This allows you, among other things, to overcome the problem of depth of field thanks to a motorised extended focus system. In this way, the software generates a fully focused photograph from several images in which only the range of microns captured by the microscope appears focused. The software itself selects the most well-focused areas from each image. To analyse the fracture we used both a digital microscope (PCE-M200) and a stereomicroscope (OLYMPUS SZ-PT).

With the aim of documenting the different features located on the surface of the crystal, and also to understand their arrangement, we obtained two gigapixel-type images. To do this, we adapted the guidelines proposed by Vergès and Morales (2014) to the lighting conditions (brightness, shaded areas, etc.) and the type of image generated by our reflected light microscope. We used the Image Composite Editor free software designed by the Microsoft Computational Photography research group. This allows the automatic assembly of panoramas with no deformation, something which is hugely important in order obtain homogeneous measurements across the entire image.

\subsection{Coating and cleaning of the sample}

In this study we chose to apply magnesium smoke to the surface of the tool, as this is a completely reversible product. Although magnesium and its derivatives have been used previously (Broadvent \& Knutsson 1975; Semenov 1964), the application method had not been clearly described. In this case, we used magnesium filings placed into a strainer, sufficiently high to place below an alcohol burner. To avoid problems with the temperature of the magnesium smoke, we used hot glue to fix the tool to a ceramic plate; this was then placed over the strainer prior to burning the magnesium. This procedure resulted in an optimal coating of the tool (Figure 4).

Although the magnesium can be removed simply by wiping, it is better to use an ultrasonic water bath to dislodge the coating from the entire sample. When cleaning the tool for microscopic analysis, we referred to the protocols published on both rock crystal and other raw materials (Fernández-Marchena \& Ollé 2016; Ollé \& Vergès 2008; Pedergnana et al. 2016; Pedergnana \& Ollé 2017).

\section{Results}

Observation by the naked-eye revealed a clear fracture of the distal tip area caused by an indeterminate impact, or an incoming projectile-like movement or incision. The thickness and sagittal profile of the lithic element does not make it particularly suitable for propulsion, however, the type of fracture on the tip seems to correspond with a SPIN-OFF (Fischer et al. 1984) (Figure 5). For this reason we believe it could have been used as a spearhead or small dagger. In accordance with this we employed both macro- and microscopic analysis to understand this contradictory information.

Macroscopically, the lancets located over the edges of the ventral side indicate that the piece had been formed over a flake, from the base of a large prism. In the same area, but on the dorsal face, we observed a battered area, from which are produced a series of reflected features. These reflected features are likely to be the result of various knapping errors. In the proximal crushed zone, there is a bipolar removal that crosses another coming from the distal portion. Although the tip area is not preserved, because of the projectile-like fracture, the fact that it only presents one removal, there is no second crushed area, and because due to its size almost the entire piece could be used as bipolar core, we do not think this piece is a core. 

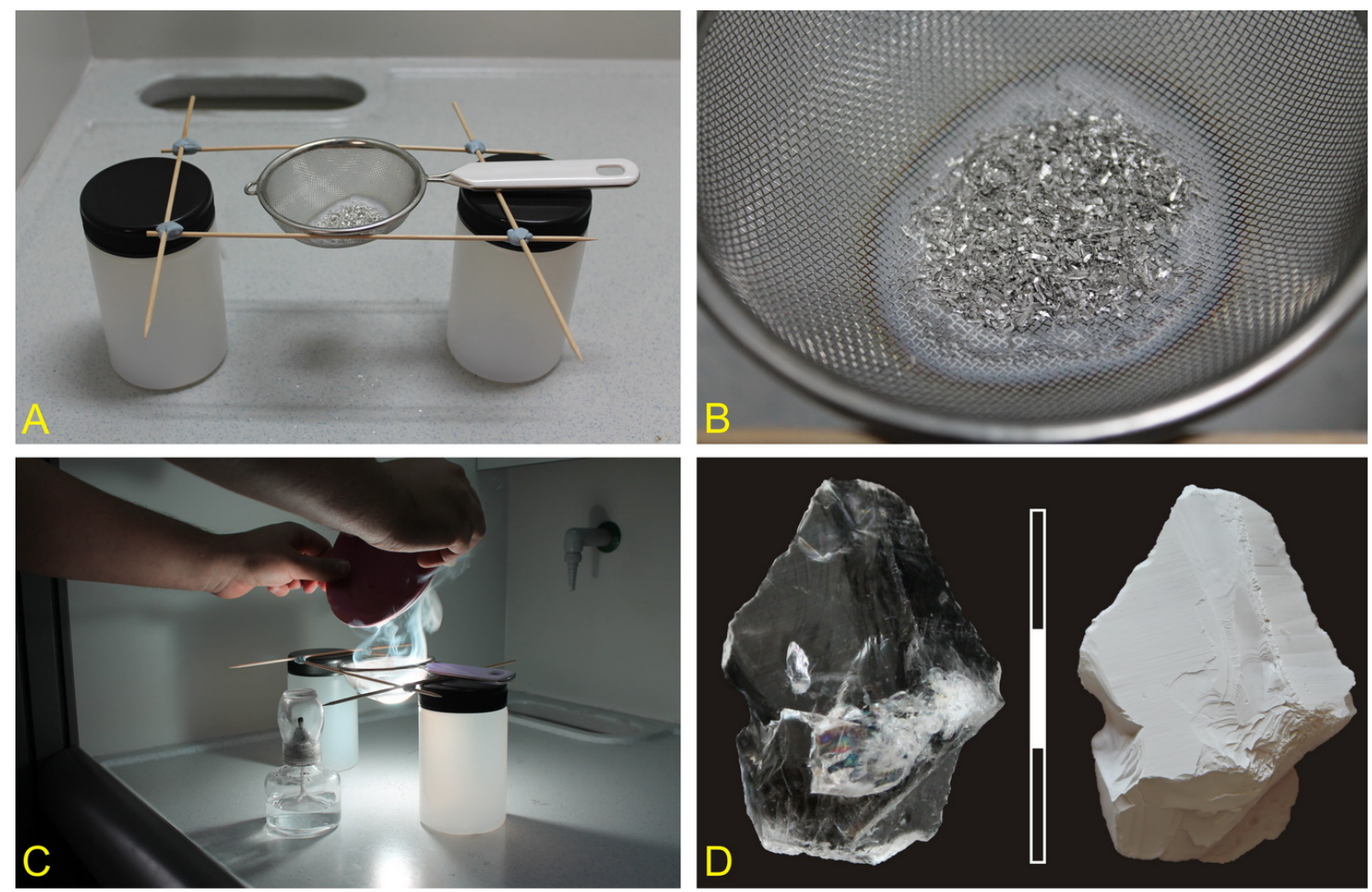

Figure 4. Process of smoking magnesium. A. Structure for the smoking process; B. Detail of the magnesium filings; C. Process of the smoking; D. The dorsal face of the tool with and without magnesium.

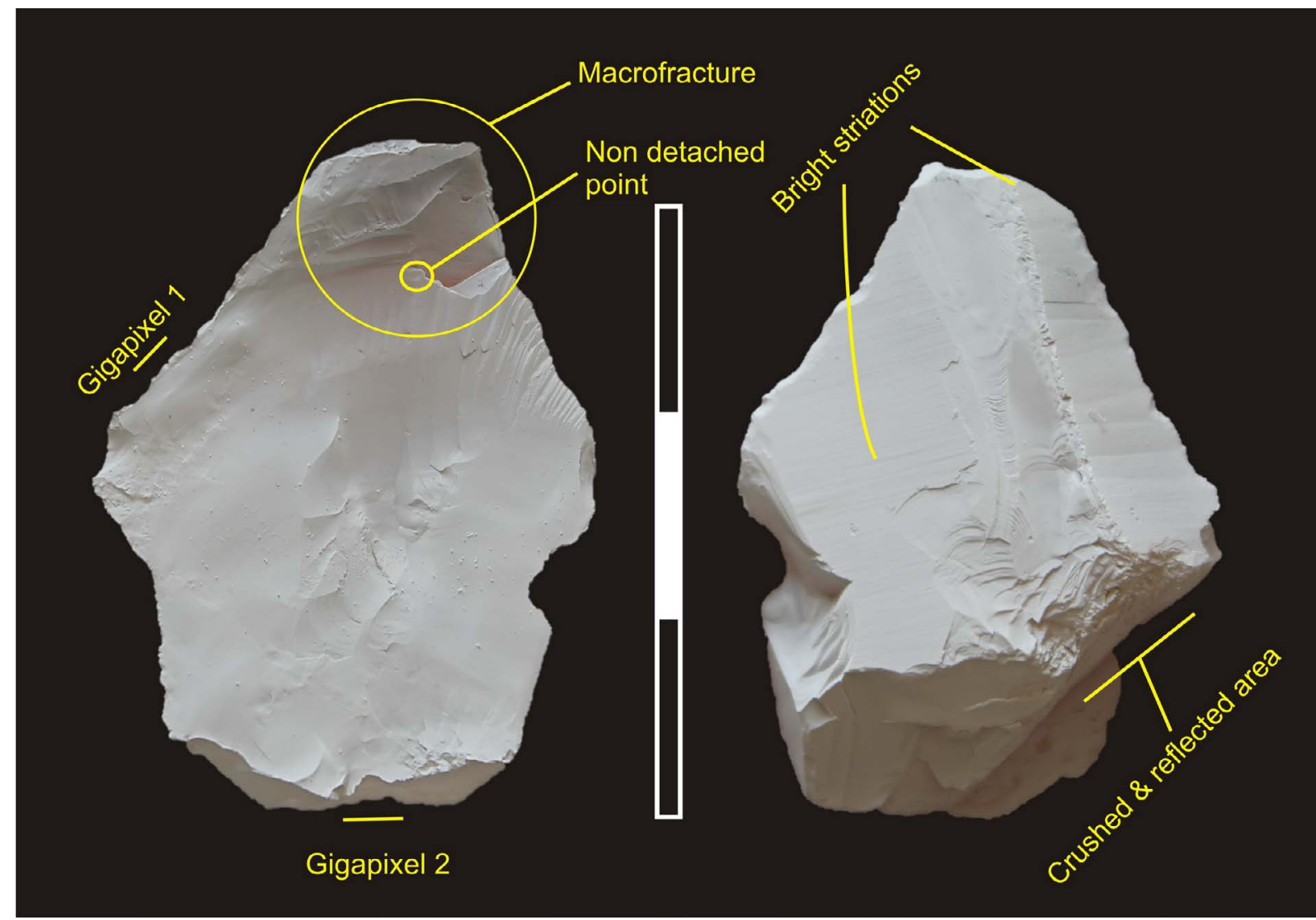

Figure 5. Both faces of the tool with the magnesium. Location of the main features described in the text. 
With regard to retouching, the most interesting aspect is the removal of the butt from the ventral side to create a flat surface where the tool probably fitted into a handle, possibly in the form of an L. The edges were configured by direct retouching. They are small removals from the distal to mesial zones. Here there are two notches, probably to facilitate the hafting.

The microscopic analysis was undertaken in two different phases. First, we observed a series of striations and fractures on the ventral face. The presence of long, wide striations across virtually the entire surface, and in different directions, led us to think at first that this was post-depositional damage. However, a posteriori, an analysis of the photographs taken of the different areas of the tool seemed to show directional patterns.

For this reason we decided to do a more in-depth microscopic analysis, adapting the proposed "gigapixel” concept (Vergès \& Morales 2014). The review was carried out with the aim of documenting areas extensive enough to assess whether or not the large striations were arranged in an orderly manner. Two "gigapixels" based on 200x image stitchings were made for the ventral side of the tool and photographed at 200x magnification. The images enclosed in the text (Figures $6 \&$ 7) are for physical reasons gigapixel-like images. (Note: The originals are available online (Fernández-Marchena 2017a; 2017b)).

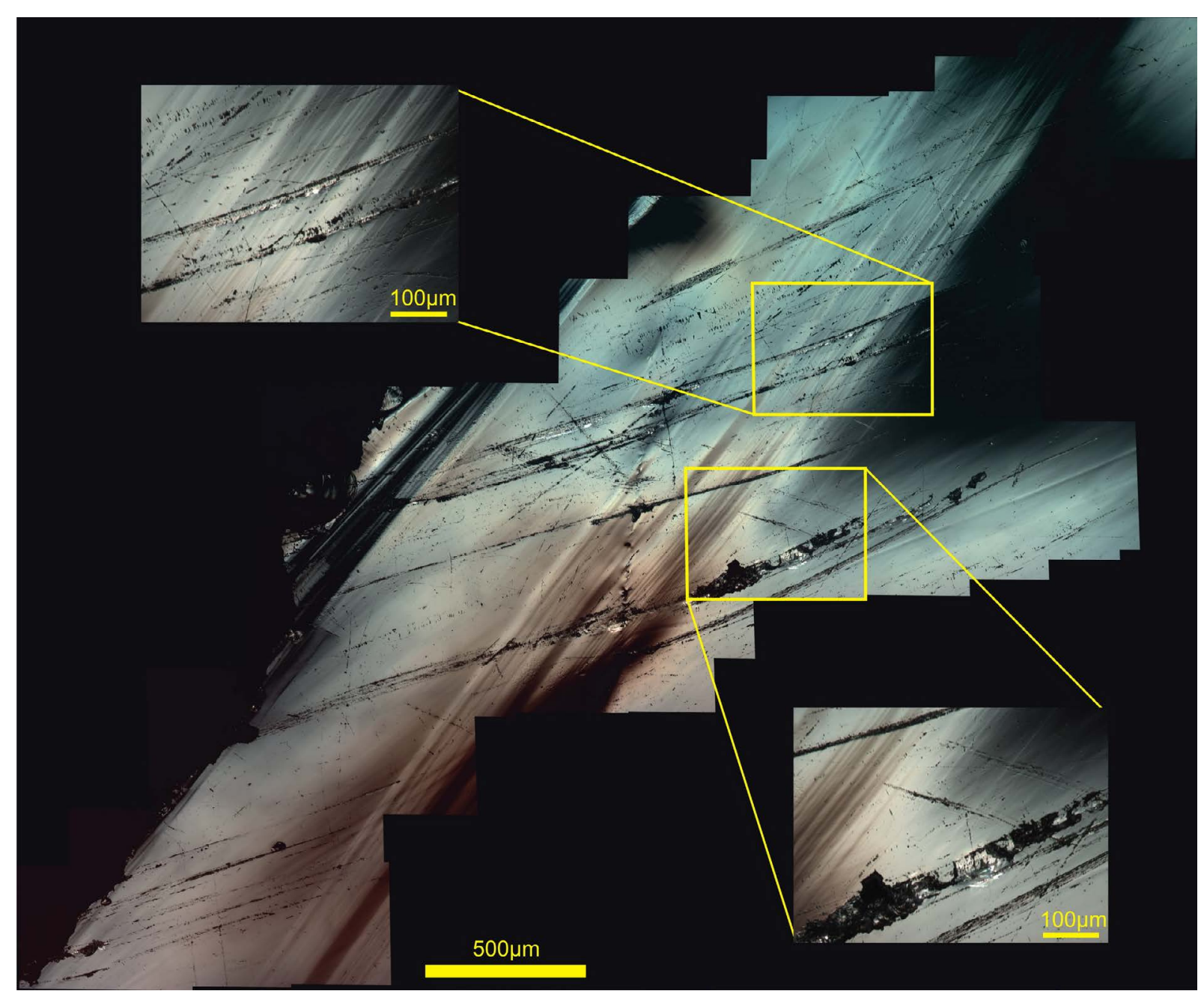

Figure 6. Gigapixel-like image (Gigapixel 1 in Figure 5); striations and percussion marks likely due to knapping errors.

The first "gigapixel" was made from 52 images from the left mesial area of the ventral face (Figure 6). It shows larger striations related with crushing marks. Therefore, and as we have documented in ongoing experimental work, these striations were probably produced 
when the knapper tried retouching the piece. These types of striations can occur due to the characteristic smooth surface of the rock crystal, which causes the hammer to slip. The fact that in the mesial area there is a higher concentration of these striations could also be related to a treatment to create a rougher surface to facilitate the tool being clamped to the handle.

The "gigapixel" image of the proximal area (Figure 7), which was made from 95 images, shows the same type of striations but with a completely different orientation to those in the first "gigapixel" picture. The orientation of these striations is also transverse to the edge, although they end in a surface formed by abrupt retouching, which generates a $90^{\circ}$ angle. Fractures and a failed removal can also be observed. Although all the striations documented on the ventral side are furrows (Ollé et al. 2016), in this area, because these striations are also formed by retouching, there are examples of the partial hertzian crack sub-type (Lawn \& Marshall 1979). The configuration of this area allows for a perfect "L"-type haft (Wadley 2005), also called juxtaposed hafted method (Rots 2010; Stordeur 1984).

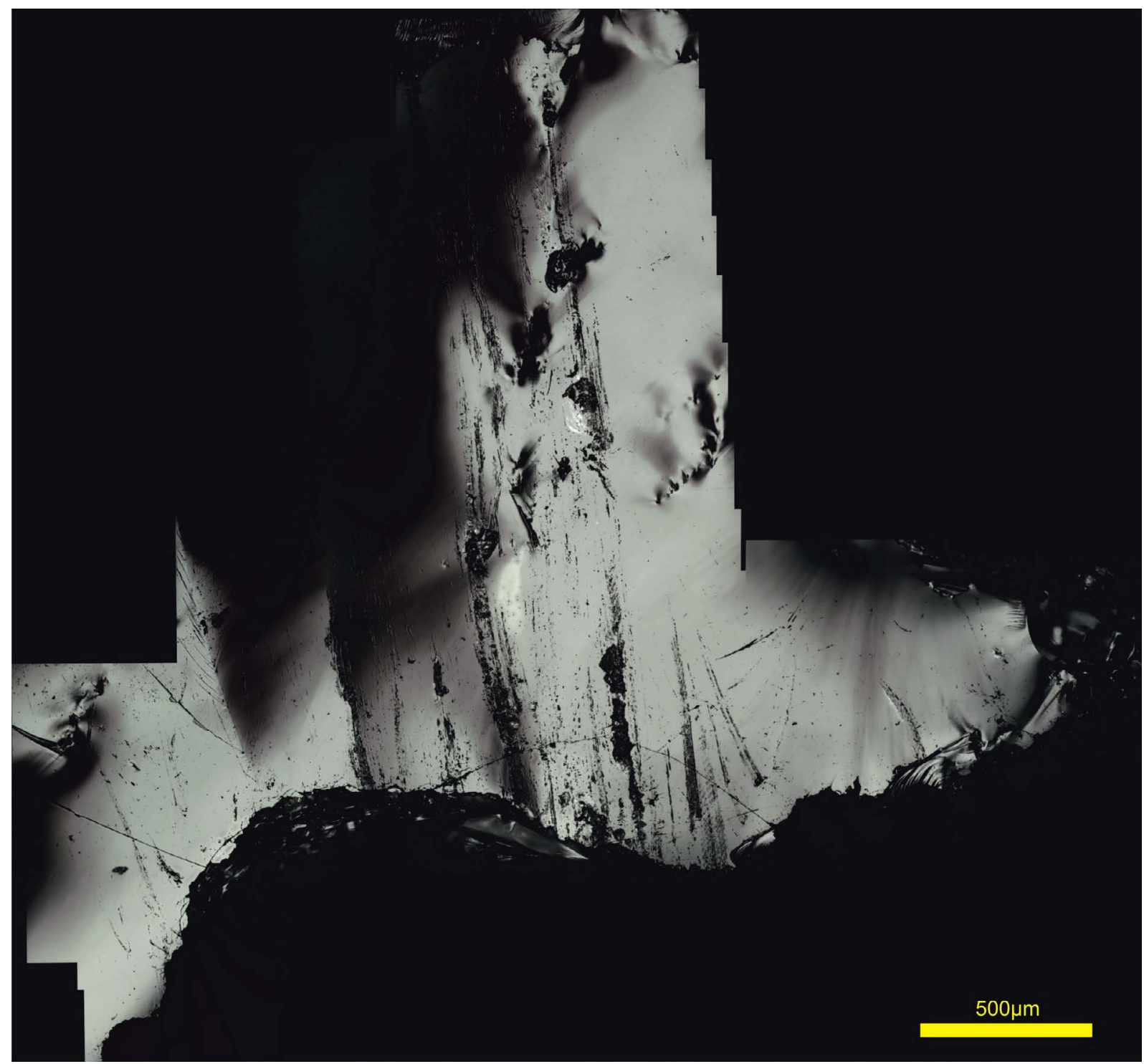

Figure 7. Gigapixel-like image (Gigapixel 2 in Figure 5) of the proximal area in which striations appear associated to percussion marks. Note the retouched area and a non-detached removal (incipient fracture) as well as associated radial fractures. In the gigapixel image (Fernández-Marchena 2017b) some partial hertzian cracks can be observed on the percussion marks. 
The dorsal side of the tool is mostly cortical. Although the cortical areas of rock crystal and other raw materials are usually not taken into account due to their state, the cortical face of this prism was perfectly preserved. We have found that these striations appear throughout the piece, all oriented in the same direction. Most are sleek type, very long and thin, and in some cases there are bright striations (Figure 8), something we have only documented in the analysis of rock crystal projectiles (Fernández-Marchena et al, in press). It should be noted that on the dorsal side of this tool, the same type of striations as observed on the ventral face were absolutely absent.
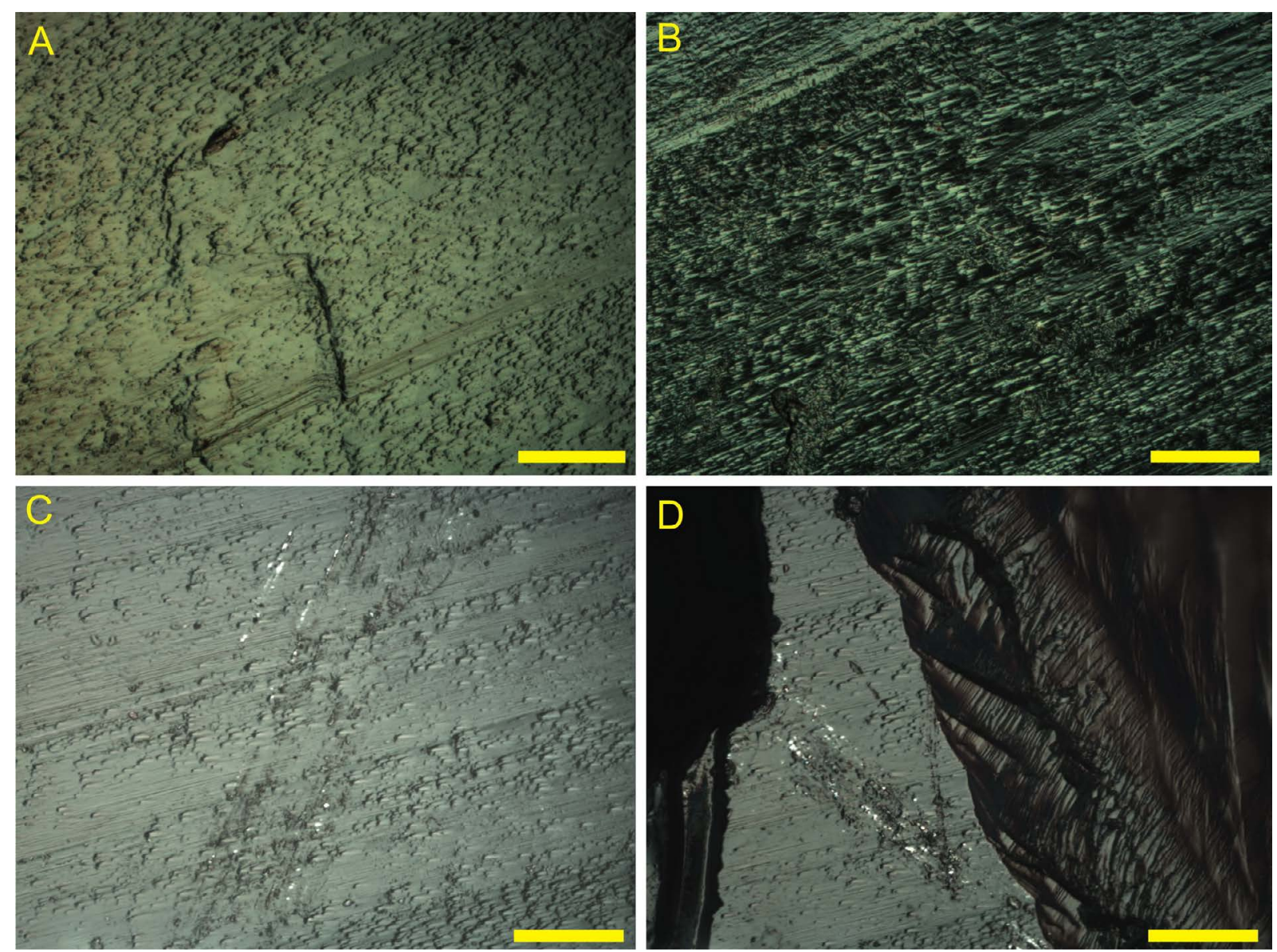

Figure 8. Details of the dorsal surface; A \& B. unaltered cortical surface; C \& D. bright striations. In image C the striations (quasi-vertical arrangement) overlap the growth lines (quasi-horizontal arrangement). The original magnification of all images is 200x and the graphic scale bars correspond are $100 \mu \mathrm{m}$.

The microscopic observation of the macro-fracture impact on the ventral side, which we consider to be a SPIN-OFF, reveals certain peculiarities as a result of the performance of this raw material. Microscopically we can see how the fracture does not end in the removed area (Figure 9). Following the terminology of Fischer and colleagues, from their adaptation of the catalogue of fractures from the HO-HO committee, in addition to a SPIN-OFF, continuity could also lead to possible inclusion in the 2C group: step terminating bending fracture (Fischer et al. 1984). Aside from the continuation of the fracture, if we change the direction of light with the Nomarski prism, we see that part of the surface is really a failed removal. This is seen as iridescence created under the fractured surface (Figure 9C \& D).

Finally, as a technical result, it is necessary to indicate that the use of smoked magnesium is only effective for macroscopic analysis. In the case of microscopic analysis, it allows observation of the chipping, but these marks are covered with a layer of dust meaning you cannot see the surface properly (Figure 10). 

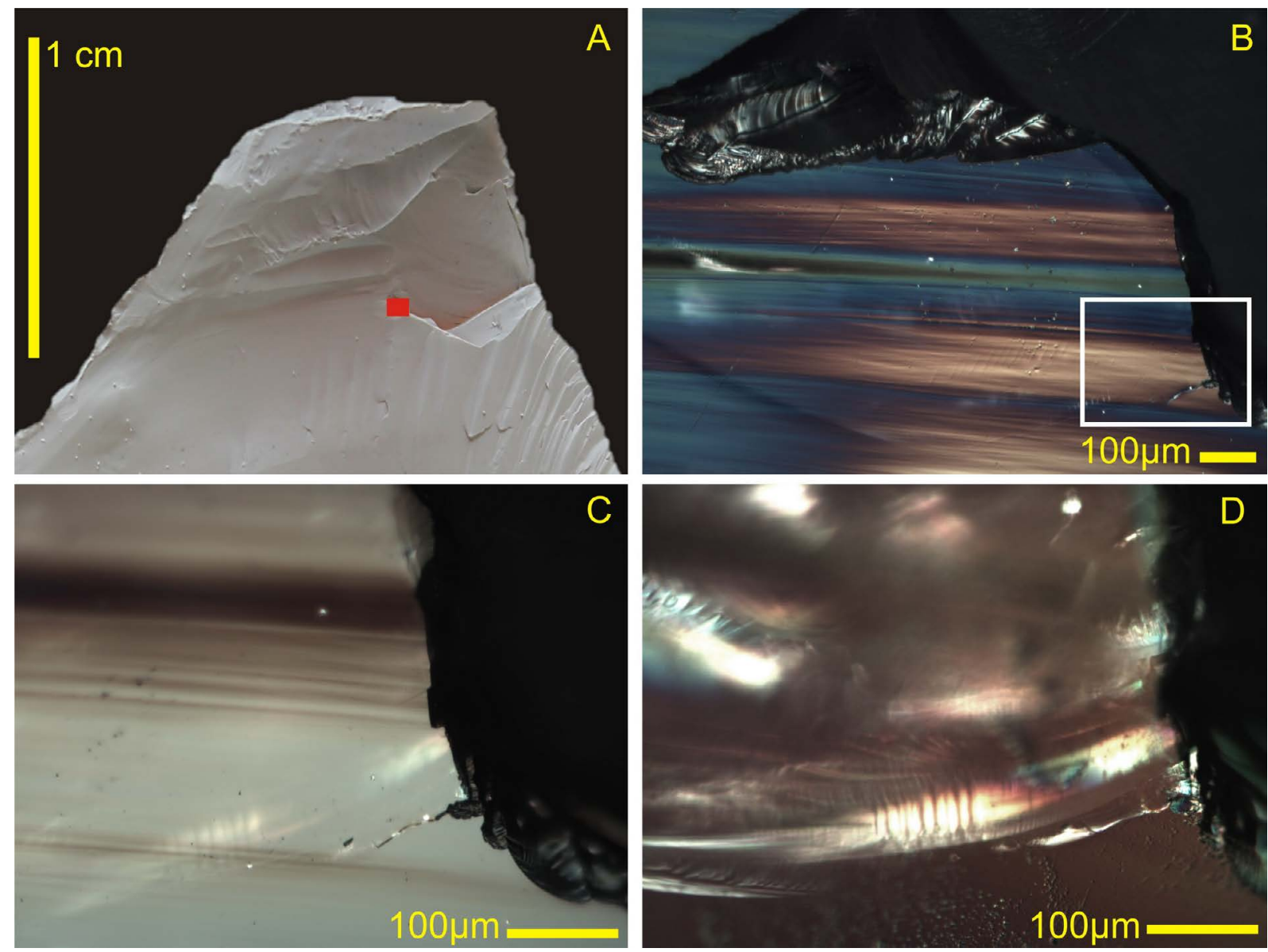

Figure 9. Impact macro-fracture in the distal area of the ventral face; A. Macro-fracture with magnesium. The red rectangle represents the area of the image B; B. Detail of the macro-fracture at 100x, the white rectangle represents the images C \& D; C \& D. The same point at 200x but with changes in the orientation of the light with the Nomarski prism. In image D it is more evident that the surface is not detached although is fractured.
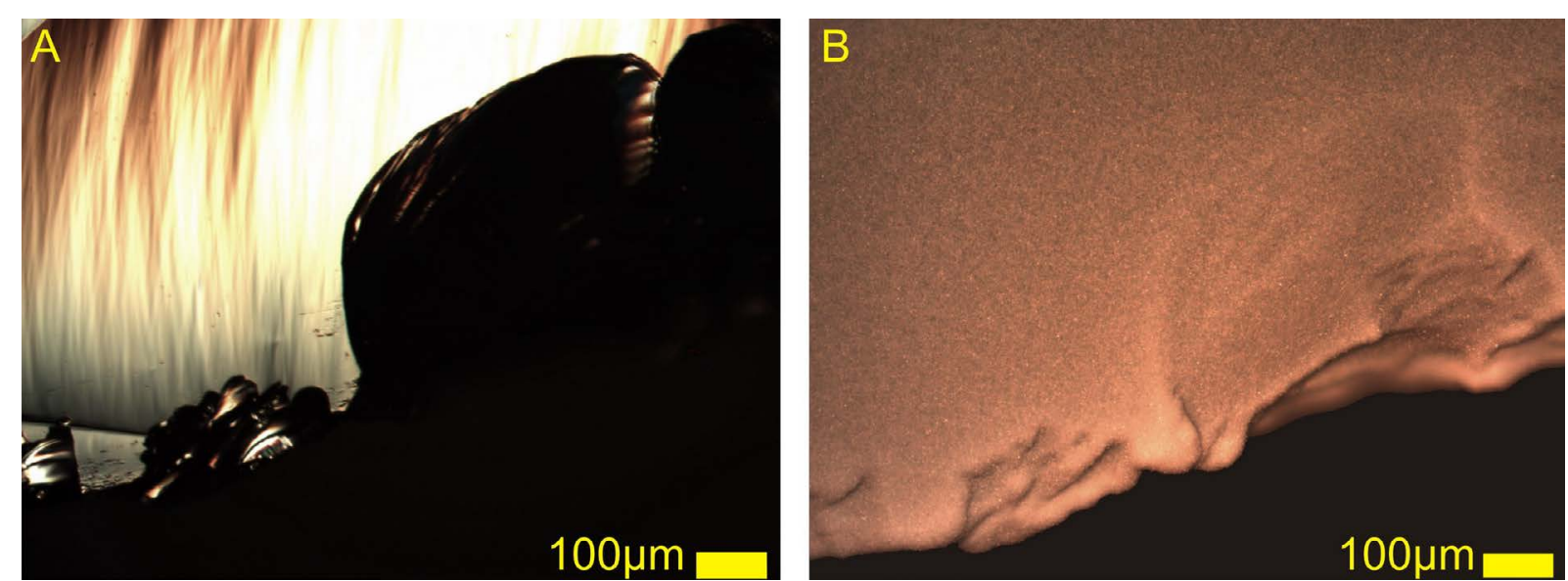

Figure 10. The same point on an experimental tool used for cutting bone at 100x; A. Area without magnesium in which it is possible to distinguish microchipping and striations; B. With the magnesium coat it is impossible to see the striations, and the morphology of the microchipping is altered.

\section{Discussion and conclusions}

The analysis of the projectile point from O Achadizo allows us to approach stone tool use by the inhabitants of the Galician Iron Age hillforts. From the three scales at which we observed the tool (a visu, macro- and microscopic), we can draw several conclusions regarding its production and use. Firstly, although the piece is slightly shaped, the presence of 
so many knapping errors, including hammer slips along the edge, indicates that the knapper tried to make a much thinner tool. Secondly, the presence of the two side notches, and the removal of the butt, indicate that this tool was made to be hafted, likely with an "L" type handle. Given its curvature, the piece does not seem to have been used as a propelled tip. Therefore, we think that it must have been hafted as a small spearhead or a small dagger-like implement (Figure 11).

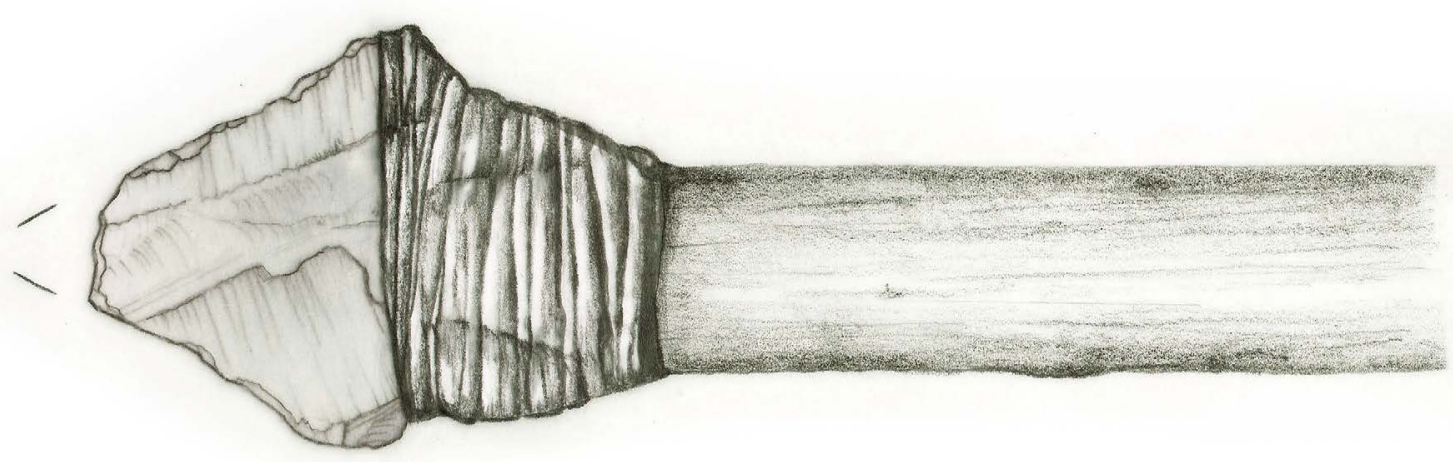

Figure 11. Ideal reconstruction of the tool hafted as a spear, taken from the microwear traces and tool morphology. No other evidence of a handle is has been found in the archaeological record of the site.

The large number of knapping errors (both macroscopic and microscopic), together with the scarcity of lithic tools in these contexts, seem to indicate an extreme reduction in the knapping tradition in the Galician Iron Age (Torres Navas \& Baena Preysler 2014). Even so, and despite the errors, this device appears to have served its purpose.

The distal macro-fracture and the appearance of bright striations on the dorsal face clearly point to the use of the tip as a sharp object or projectile. Although the striations on the ventral side are due to technical processes, some of those formed in the proximal area could be due to the haft, and not only the retouching. Unfortunately these cannot be differentiated.

Despite the properties of this rock crystal making it good for cutting activities (Fernández-Marchena \& Ollé 2016), as with quartz in general (Bracco \& Morel 1998), there is no documented microscopic evidence of it being used for this activity. Although there is an ongoing study of the fauna at the site (Pérez-Tenorio et al. 2015) the data obtained so far indicates that all the cut marks were made with metal knives.

\section{Final remarks}

In conclusion, it should be noted that the data obtained in this work, despite coming from just a single tool, allows a certain degree of interpretation. The use of the object as a hafted incisive tool and the fact it was discarded after being fractured may invalidate a sumptuary or symbolic interpretation, so often argued when discussing of rock crystal artefacts.

On the other hand, the scarce evidence of knapped lithic elements in the hillforts, and the belief of archaeologists that these elements do not provide information on the economy of these settlements, are the main obstacles in the proper assessment of these materials. This underestimation is accentuated by the fact that in the Galician area the main knapped material is vein quartz, a more difficult material to read than, for example, flint. However, we do not agree that this is a valid excuse, and we strongly argue the need to catalogue all the knapped elements. Unfortunately, the dig model chosen for this type of archaeological sites in recent years has favoured neither proper, comprehensive data collection, nor the selection of specialised researchers, trained workers or students for the archaeological campaigns. 


\section{Acknowledgements}

We would like to thank Pepa Rey Castiñeira, Ángel Concheiro and the Archaeological Centre of Barbanza, for the cession of the tool presented in this work and facilities to study it in. We also want to thank Xavier Mangado, conference organizer of the "On the Rocks", for his help so that the lead author could attend and present this work. J. L. F.-M. is the beneficiary of a pre-doctoral FPI grant from the MINECO (BES-2015-074931). A. A. R.-N. is the beneficiary of a pre-doctoral grant from the I2C plan of the Xunta de Galicia. We also thank Gala García-Argudo Ripoll for her assistance with the layout of the poster presented at the congress, to Josep Maria Vergès for his comments about the aerodynamics of the projectiles, and to Juan Ignacio Morales Hidalgo for his advice regarding the presentation of "gigapixels". This work was developed within the framework of the projects CGL201565387-C3-1-P (MINECO/FEDER), SGR 2014-899 (AGAUR), 2014/2015/2016-PFRURVB2-17 (URV).

\section{References}

Asryan, L., Ollé, A., Moloney, N. 2014, Reality and confusion in the recognition of postdepositional alterations and use-wear: An experimental approach on basalt tools. Journal of Lithic Studies, 1(1): 9-32. doi:10.2218/jls.v1i1.815

Ayán Vila, X.M. 2012a, Campo de traballo arqueolóxico no Castro Grande de O Neixón 2004. Sondaxes e escavación arqueolóxica no Castro Grande de Neixón (Boiro, A Coruña). (technical report). Laboratorio de Arqueoloxía da Paisaxe, Instituto de Estudos Galegos Padre Sarmiento, Santiago de Compostela, 230 p. (in Galician) ("Sounded and excavation in Castro Grande de Neixón (Boiro, A Coruña)")

URL: http://hdl.handle.net/10261/48489

Ayán Vila, X. M. 2012b, Escavación arqueolóxica no Castro Grande de Neixón (Boiro, A Coruña). Campaña de 2005. (technical report). Laboratorio de Arqueoloxía da Paisaxe, Instituto de Estudos Galegos Padre Sarmiento, Santiago de Compostela, 394 p. (in Galician) (“Archaeological excavation in Castro Grande de Neixón (Boiro, A Coruña)”) URL: http://hdl.handle.net/10261/48384

Ayán Vila, X. M. 2012c, Escavación arqueolóxica no Castro Grande de Neixón (Boiro, A Coruña). Campaña de 2006. (technical report). Laboratorio de Arqueoloxía da Paisaxe, Instituto de Estudos Galegos Padre Sarmiento, Santiago de Compostela, 360 p. (in Galician) (“Archaeological excavation in Castro Grande de Neixón (Boiro, A Coruña)”) URL: http://hdl.handle.net/10261/48400

Ayán Vila, X. M. 2012d, Escavación arqueolóxica nos Castros de Neixón (Boiro, A Coruña). Campaña de 2008. (technical report). Laboratorio de Arqueoloxía da Paisaxe, Instituto de Estudos Galegos Padre Sarmiento, Santiago de Compostela, 172 p. (in Galician) (“Archaeological excavation in Castro Grande de Neixón (Boiro, A Coruña)”) URL: http://hdl.handle.net/10261/48413

Ayán Vila, X. M. \& Gianotti García, C, 2006. Escavación arqueolóxica no Castro Grande de Neixón (Boiro, A Coruña). Campaña de 2003. (technical report). Laboratorio de Arqueoloxía da Paisaxe, Instituto de Estudos Galegos Padre Sarmiento, Santiago de Compostela, 105 p. (in Galician) ("Archaeological excavation in Castro Grande de Neixón (Boiro, A Coruña)”) URL: http://hdl.handle.net/10261/48373 
Bracco, J.-P. \& Morel, P. 1998, Outillage en quartz et boucherie au Paléolithique Supérieur: Quelques observations expérimentales. In: Économie préhistorique: Les comportements de subsistance au Paléolithique (Brugal, J. P., Meignen, L. \& Patou-Mathis, M., Eds.), 13e Rencontres Internationales d'Archéologie et d'Histoire d'Antibes. Éditions Association pour la Promotion et la Diffusion des Connaissances Archéologiques. Sophia-Antipolis: 387-395 p. (in French) ("Prehistoric economy: Subsistence behaviors in the Paleolithic")

Bonilla Rodríguez, A. \& Fábregas Valcarce, R. 2011, Sondaxes arqueolóxicas e labores de restauro no complexo dos castros de Neixón (Boiro, A Coruña). (technical report). Grupo de Estudos para a Prehistoria do Noroeste Ibérico - Universidade de Santiago de Compostela (GEPN-USC) and P \& A Arqueólogos, Santiago de Compostela, 219 p. (in Galician) ("Archaeological soundings and restoration works in the Neixón complex hillforts”)

Brink, J. 1978, The role of abrasives in the formation of lithic use-wear. Journal of Archaeological Science, 5(4): 363-371. doi:10.1016/0305-4403(78)90055-9

Broadvent, N. D. \& Knutsson, K. 1975, An experimental analysis of quartz scrapers. Results and applications. Fornvännen, 70: 113-128.

Cancela Cereijo, C. 2006, Material lítico. In: O Castro de Montealegre, Moaña Pontevedra (Aboal Fernández, R. \& Castro Hierro, V., Eds.), Editorial Toxosoutos, Noia: p. 205234. (in Galician) ("Lithic material”)

Cano Pan, J. A. 1985, La industria lítica en la cultura castreña de Galicia, Tesis de licenciatura inédita (unpublished undergraduate thesis). Universidade de Santiago de Compostela, Santiago de Compostela, 160 p. (in Spanish) ("The lithic industry in the Castro-culture of Galicia”)

Cano Pan, J. A. 1987, La industria lítica castreña: Los tipos y sus técnicas de talla, Gallaecia, 9: 7-26. (in Spanish) (“The hillforts' lithic industry: Types and knapped techniques”)

Cano Pan, J. A. \& Vázquez Varela J. M. 1987, Nuevos datos y perspectivas sobre las industrias líticas de la costa S.O. de Galicia, Castrelos: Revista do Museo Municipal “Quiñones de León”, 0: 33-38. (in Spanish) ("New data and perspectives about lithic industries of the SW coast of Galicia”)

Concheiro Coello, A. 2008, Castro do Achadizo. Cultura material, economía de subsistencia na Idade do Ferro. Memoria das escavacións 1991-1994. Concello de Boiro, Boiro, 80 p. (in Galician) (“Achadizo hillfort. Material culture, subsistence economy in the Iron Age”)

Ferré, M. C., Rey, J. M., Concheiro, A., Vázquez Varela, J. M. 1996, Contribución al conocimiento ictiológico del Castro de “O Achadizo” (Cabo de Cruz, Coruña, Galicia). In: Biogeografía Pleistocena-Holocena de la Península Ibérica (Ramil Rego, P., Fernández Rodríguez, C. \& Rodríguez Guitián, M., Eds.), Universidad de Santiago, Santiago de Compostela: p. 291-296. (in Spanish) ("Contribution to ichthyology knowledge of “O Achadizo” hillfort (Cabo de Cruz, Coruña, Galicia)”)

Fernández-Marchena 2017a, Gigapixel 1: left lateral edge. Researchgate. Retrieved 08 May 2017. doi:10.13140/RG.2.2.20324.17287/1

Fernández-Marchena 2017b, Gigapixel 2: proximal area. Researchgate. Retrieved 08 May 2017. doi:10.13140/RG.2.2.17807.59045 
Fernández-Marchena, J. L. \& Ollé, A. 2016, Microscopic analysis of technical and functional traces as a method for the use-wear analysis of rock crystal tools, Quaternary International, 424: 171-190. doi:10.1016/j.quaint.2015.10.064

Fernández-Marchena, J. L., Rabuñal Gayo, J. R., García-Argudo Ripoll, G. in press, Experimental and functional analyses of rock crystal projectiles. In: Playing with the time. Experimental archaeology and the study of the past (Alonso, R., Canales, D. \& Baena, J., Eds.), Servicio de Publicaciones de la Universidad Autónoma de Madrid, Madrid: 8 p.

Fischer, A., Vemming Hansen, P., Rasmussen, P. 1984, Macro and microwear traces on lithic projectile points. Journal of Danish Archaeology, 3: 19-46.

González Pérez, L. \& Ayán Vila, X. M., 2012, Escavación arqueolóxica no Castro Grande de Neixón (Boiro, A Coruña). Campaña de 2007. (technical report). Laboratorio de Arqueoloxía da Paisaxe, Instituto de Estudos Galegos Padre Sarmiento, Santiago de Compostela, 379 p. (in Galician) ("Archaeological excavation in Castro Grande de Neixón (Boiro, A Coruña)”) URL: http://hdl.handle.net/10261/48403

González Ruibal, A. 2005, Resultados das sondaxes nun xacemento atípico da Idade do Ferro: Pena redonda (Pontecaldelas, Pontevedra). Cuadernos de Estudios Gallegos, 52(118): 173-197. (in Galician) ("Results of the soundings in an atypical site of the Iron Age: Pena Redonda (Pontecaldelas, Pontevedra)”) doi:10.3989/ceg.2005.v52.i118.93

Grace, R. 1996, Use-wear analysis: State of the art. Archaeometry, 38(2): 209-229. doi:10.1111/j.1475-4754.1996.tb00771.x

Greenfield, H. J. 1999. The origins of metallurgy: Distinguishing stone from metal cut-marks on bones from archaeological sites. Journal of Archaeological Science, 26(7): 797-808. doi:10.1006/jasc.1998.0348

Gutiérrez Sáez, C., González Urquijo, J. E., Ibáñez Estévez, J. J. 1988, Alteraciones microscópicas en el tratamiento convencional del material lítico: Su incidencia en las huellas de uso. Munibe (Antropologia-Arkeologia) Suplemento, 6: 83-89. (in Spanish) ("Microscopic alterations in the conventional treatment of lithic material: Its impact on traces of use”)

Igreja, M. 2009, Use-wear analysis of non-flint stone tools using DIC microscopy and resin casts: A simple and effective technique. In: Recent Functional Studies on Non-Flint Stone Tools: Methodological Improvements and Archaeological Inferences, Proceedings of the Workshop 23-25 May 2008, Lisboa - Proceedings of the Workshop [CDROM] (Clemente, I., \& Igreja, M., Eds.), Methodological Improvements and Archaeological Inferences Workshop, Lisboa: 20 p.

Kamminga, J. 1979, The nature of use-polish and abrasive smoothing on stone tools. In: Lithic Use-Wear Analysis (Hayden, B., Ed.), Studies in Archaeology, Academic Press, New York: p. 143-157.

Keeley, L. H. 1974, Technique and methodology in microwear studies: a critical review. World Archaeology, 5(3): 323-336. doi:10.1080/00438243.1974.9979577

Keeley, L. H. 1980, Experimental determination of stone tool uses: A microwear analysis. University of Chicago, Chicago, 212 p.

Lawn, B. R. \& Marshall, D. B. 1979, Mechanisms of microcontact fracture in brittle solids. In: Lithic Use-Wear Analysis (Hayden, B., Ed.), Studies in Archaeology, Academic Press, New York: p. 63-82. 
Levi-Sala, I. 1986, Use-wear and post-depositional surface modification: A word of caution. Journal of Archaeological Science, 13: 229-244. doi:10.1016/0305-4403(86)90061-0

Levi-Sala, I. 1996, A study of microscopic polish on flint implements. BAR International Series Vol. 629. Tempus Reparatum, Oxford, 178 p.

Marreiros, J., Mazzucco, N., Gibaja, J. F., Bicho, N. 2015, Macro and micro evidences from the past: The state of the art of archeological use-wear studies. In: Use-wear and residue analysis in archaeology (Marreiros, J. M., Ferreira Bicho N. \& Gibaja Bao, J. F., Eds.), Springer, London: p. 5-26. doi:10.1007/978-3-319-08257-8_2

Odell, G. H. 1975, Micro-wear in perspective: A sympathetic response to Lawrence H. Keeley. World Archaeology, 7(2): 226-240. doi:10.1080/00438243.1975.9979635

Odell, G. H. 1981, The mechanics of use-breakage of stone tools: Some testable hypotheses. Journal of Field Archaeology, 8(2): 197-209. doi:10.1179/009346981791505120

Odell, G. H. \& Odell-Vereecken, F. 1980, Verifying the reliability use-wear assesments by "blind-tests": The low-power approach. Journal of Field Archaeology, 7(1): 87-120. doi:10.1179/009346980791505545

Olausson, D. 1993, Review of the interpretative possibilities of microwear studies. Fornvännen, (Graslund, B., Knutsson, H., Knutsson, K. \& Taffinder J., Eds.) 88: 94-98.

Ollé, A. \& Vergès, J. M. 2008, SEM functional analysis and the mechanism of microwear formation. In: 'Prehistoric Technology' 40 years later: Functional Studies and the Russian Legacy. Proceedings of the International Congress Verona (Italy), 20-23 April 2005 (Longo, L. \& Skakun, N., Eds.), B.A.R. International Series Vol. 1783, Archaeopress, Oxford: p. 39-49.

Ollé, A. \& Vergès, J. M. 2014, The use of sequential experiments and SEM in documenting stone tool microwear. Journal of Archaeological Science, 48: 60-72. doi:10.1016/j.jas.2013.10.028

Ollé, A., Pedergnana, A., Fernández Marchena, J. L., Martin, S., Borel, A., Aranda, V. 2016, Microwear features on vein quartz, rock crystal and quartzite: A study combining Optical Light and Scanning Electron Microscopy, Quaternary International, 424: 154170. doi:10.1016/j.quaint.2016.02.005

Pargeter, J. 2011, Assessing the macrofracture method for identifying Stone Age hunting weaponry. Journal of Archaeological Science, 38: 2882-2888. doi:10.1016/j.jas.2011.04.018

Pargeter, J. 2013, Rock type variability and impact fracture formation: working towards a more robust macrofracture method. Journal of Archaeological Science, 40(11): 40564065. doi:10.1016/j.jas.2013.05.021

Pargeter, J. \& Bradfield, J. 2012, The effects of Class I and II sized bovids on macrofracture formation and tool displacement: Results of a trampling experiment in a southern African Stone Age context. Journal of Field Archaeology, 37(3): 238-251. doi:10.1179/0093469012Z.00000000022

Pedergnana, A., Asryan, L., Fernández-Marchena, J. L., Ollé, A. 2016, Modern contaminants affecting microscopic residue analysis on stone tools: A word of caution. Micron, 86: 121. doi:10.1016/j.micron.2016.04.003 
Pedergnana, A. \& Ollé, A. 2017, Monitoring and interpreting the use-wear formation processes on quartzite flakes through sequential experiments, Quaternary International, 427B: 35-65. doi:10.1016/j.quaint.2016.01.053

de la Peña Santos, A. 1992, Castro de Torroso (Mos, Pontevedra). Síntesis de las Memorias de las campañas de excavaciones 1984-1990. Arqueoloxía-Memorias Vol. 11, Xunta de Galicia, Santiago de Compostela, 171 p. (in Spanish) ("Torroso hillfort (Mos, Pontevedra). Synthesis of the memories of the fieldwork campaigns”)

Pérez-Tenorio, R., Saladié, P., Fernández Rodríguez, C., Seoane Novo, C., Amado Rodríguez, E., Rodríguez Nóvoa, A. A., Fernández-Marchena, J. L. (2015) New data about faunal assemblages of the archaeological site of $O$ Achadizo. Oral presentation at the Postgraduate Archaeozoological Forum (5 $\left.{ }^{\text {th }}\right)$, Tarragona, 24-26 September.

Pignat, G. \& Plisson, H. 2000, Le quartz, pour quel usage? l'outillage Mesolithique de Vionnaz (Suisse) et l'apport de la traceologie. In: MESO'97. Actes de la table ronde "Epipaléolithique et Mésolithique” (Crotti, P., Ed.), Cahiers d'Archeologie Romande Vol. 81. Musée Cantonal d'Archéologie et d'Histoire, Lausanne: p. 65-87. (in French) ("Quartz, for what purpose? The Mesolithic tools of Vionnaz (Switzerland) and the contribution of Traceology”)

Plisson, H. 1985, Etude fontionnelle d'outillages lithiques préhistoriques par l'analyse des micro-usures: Recherche méthodologique et archéologique. Thèse de doctorat, Université de Paris I, Panthéon Sorbonne, Paris, 357 p. (in French) ("Functional study of prehistoric stone tools by analyzing the micro-wear: Methodological and Archaeological Research”)

Plisson, H. 2008. Fonction(s) d'un racloir en cristal de roche. In: Artisanats et territoires des chasseurs moustériens de Champ Grand. (Slimak, L., Eds.), Artisantas \& Territoires Vol. 1, Maison méditerranéenne des Sciences de l'Homme, Aix-en-Provence: p. 386399. (in French) ("Function(s) of a rock crystal scraper")

Plisson H. \& Mauger, M. 1988, Chemical and mechanical alteration of micro-wear polishes: An experimental approach. Helinium, 28: 3-16.

Ramil Rego, E., Fernández Rodríguez, C., Rodríguez López, C., Fernández Pintos, P. 1995, El yacimiento de Punta do Castro (Reinante, Barreiros, Lugo): Materiales de superficie y perspectivas. Férvedes, 2: 87-115. (in Spanish) ("The site of Punta do Castro (Reinante, Barreiros, Lugo): Materials in surface and perspectives”)

Rodríguez López, C., Fernández Rodríguez, C., Ramil Rego, E. 1993, El aprovechamiento del medio natural en la cultura Castreña del Noroeste Peninsular. Trabalhos de Antropologia e Etnologia, 33: 285-305. (in Spanish) ("The exploitation of the natural environment in the Castro-culture of Northwestern peninsula")

Rots, V. 2010, Prehension and hafting traces on flint tools. A methodology. Leuven University Press, Leuven, 273 p.

Rubinos Pérez, A., Fábregas Valcarce, R., Alonso Mathias, F., Concheiro Coello, A. 1999, Las fechas c-14 del castro de O Achadizo (Boiro, A Coruña): Problemática de la calibración de conchas marinas. Trabajos de Prehistoria, 56(1): 147-155. (in Spanish) ("Radiocarbon dates of the Iron Age hillfort of O Achadizo (Boiro, A Coruña, NW Iberia): An approach to the dating of marine shells”) doi:10.3989/tp.1999.v56.i1.296 
Semenov, S.A. 1964, Prehistoric Technology: An experimental study of the oldest tools and artefacts from traces of manufacture and wear. (translated by Thompson, M.W.). Cory, Adams and Mackay, London, 211 p.

Shea, J. J. \& Klenck, J. D. 1993, An experimental investigation of the effects of trampling on the results of lithic microwear analysis. Journal of Archaeological Science, 20: 175194. doi:10.1006/jasc.1993.1013

Stordeur, D. 1987, Manches et enmanchements préhistoriques: Quelques prepositions préliminaires. In: Le main et l'outil. Manches et enmanchements préhistoriques (Stordeur, D., Ed.), Maison de l'Orient et de la Méditerranée Jean Poilloux, Lyon: p. 1134. (in French) ("Prehistoric hafts and hafting: Some preliminary proposals")

URL: http://www.persee.fr/doc/mom_0766-0510_1987_act_15_1_1683

Torres Navas, C. \& Baena Preysler, J. 2014. Querer hacer y poder hacer: La variabilidad en las industrias líticas y su relación con las habilidades técnicas y tecnológicas. In:

Homenaje a la profesora Catalina Galán Saulnier (Berrocal Ranger, L. Ed.), Ediciones Universidad Autónoma de Madrid, Madrid: p. 13-22. (in Spanish) ("Wanting to do and be able to: Variability in lithic industries and its relation to the technical and technological skills”)

Tringham, R., Cooper, G., Odell, G. H., Voytek, B., Whitman, A. 1974, Experimentation in the formation of edge damage: A new approach to lithic analysis. Journal of Field Archaeology, 1(1-2): 171-196. doi:10.1179/jfa.1974.1.1-2.171

Vergès, J. \& Morales, J. I. 2014, The gigapixel image concept for graphic SEM documentation. Applications in archeological use-wear studies. Micron, 65: 15-19. doi:10.1016/j.micron.2014.04.009

Wadley, L. 2005, Putting ochre to the test: Replication studies of adhesives that may have been used for hafting tools in the Middle Stone Age. Journal of Human Evolution, 49: 587-601. doi:10.1016/j.jhevol.2005.06.007

Yamada, S. 1993, The formation process of “Use-wear polishes". In: Traces et fonction: Les gestes retrouvés (Anderson, P., Beyries, S., Otte, M. \& Plisson, H., Eds.), Études et Recherches Archéologiques de l'Université de Liège Vol. 50, (2 vol.), Centre national de la recherche scientifique (CNRS) \& Universite de Liége, Liége: p. 433-444. 